$\begin{array}{ll} & \text { Etnográfica } \\ \text { etnográfica } & \text { Revista do Centro em Rede de Investigação em }\end{array}$

Antropologia

vol. $15(2) \mid 2011$

Vol. $15(2)$

\title{
Harry West, Kupilikula: o Poder e o Invisível em Mueda, Moçambique
}

\section{Mike McGovern}

\section{OpenEdition}

\section{Journals}

Electronic version

URL: https://journals.openedition.org/etnografica/999

DOI: 10.4000/etnografica.999

ISSN: 2182-2891

\section{Publisher}

Centro em Rede de Investigação em Antropologia

\section{Printed version}

Date of publication: 1 June 2011

Number of pages: 401-402

ISSN: 0873-6561

\section{Electronic reference}

Mike McGovern, "Harry West, Kupilikula: o Poder e o Invisivel em Mueda, Moçambique", Etnográfica

[Online], vol. 15 (2) | 2011, Online since 23 October 2011, connection on 10 February 2022. URL: http:// journals.openedition.org/etnografica/999 ; DOI: https://doi.org/10.4000/etnografica.999

\section{(c) (7) (2)}

Etnográfica is licensed under a Creative Commons Attribution-NonCommercial 4.0 International License. 
McGovern's dicta about the wars in Troy and Côte d'Ivoire is that both show us that "destiny" is the product of humans' making. So is tragedy: a mixture of feelings, histories, coincidences, intentions, manipulations, memories and expectations. "Bricollaging" with all this, humans often make do, but sometimes make war too. Whether Ivorians can escape their destiny lies indeed in human hands. Again, as McGovern writes, the Ivorian war has not yet happened, but it now seems that more and more people are very good at making it. Let us hope

\section{Harry West}

KUPILIKULA: O PODER

E O INVISÍVEL EM MUEDA, MOÇAMBIQUE

Lisbon, Imprensa de Ciências Sociais, 2009, 436 pp.

Few books on "apparently irrational beliefs" such as witchcraft achieve the analytical subtlety of Evans-Pritchard's Witchcraft, Oracles and Magic Among the Azande. Equally few achieve the organizational elegance of Evans-Pritchard's The Nuer. Amazingly, Harry West's Kupilikula compares favourably to Evans-Pritchard's two most famous books on both scores.

The book consists of an extended analysis of uwavi, or witchcraft, as an idiom for understanding and managing power amongst the mostly Makonde inhabitants of the Mueda plateau in northern Moçambique. This is the area where the Frelimo insurgency began, and West discusses this period at length, but also delves back to the beginning of the twentieth century. From the beginning, he shows the positive and negative aspects there is also a Penelope somewhere, secretly unweaving at night such tragedy-oriented fabric so blatantly woven at daylight. Whatever the destiny of the country might be, McGovern's original analysis of "war making" is no doubt destined to become an anthropological model to the study of conflict in Africa and beyond.

\section{Ramon Sarró}

Instituto de Ciências Sociais da Universidade de Lisboa, Portugal; Yale University, USA

of witchcraft, an idiom that is similar to a kind of heightened capacity, one that can be used for good or for ill. Alongside uwavi, a second key term of the text is kupilikula, the practice from which the book takes its name. This polysemic term can mean many things, including a "decisive unmaking and remaking of another's exercise of power", a "countermaneuver", or an "inversion".

Among the book's many qualities is the interplay between West's fine fieldwork and his sensitive writing. It is a testament to his fieldwork that he had 29 vignettes - one for each chapter, plus one for the preface - all rich enough to form the basis of a chapter. West uses a light hand to let readers participate in the crafting of the analysis. The reader also sees how well West's own framing of others' speech allows us to participate in their extraordinary eloquence. In describing one elderly man's oration, West writes, "Like a praise poem, the name Malapende rolled off Lyulagwe's lips and settled into the crevices between the two dozen people who now surrounded us" (p. 89 of original edition from The University of Chicago Press, 2005). 
The book is broken into three parts. The first third of the book consists of eight short chapters introducing the constituent elements of the moral grammar of uwavi. This, he tell us, will be our prism for understanding Muedan $20^{\text {th }}$ century history. The elements include the link between uwavi and slavery, the significance of kinship links, the notion of kushulula, or insatiable appetite, the work of healers and the medicines they use, and finally two subsidiary types of uwavi, uwavi wa kupika, sorcery of fabrication (as of sorcerer-lions), and uwavi wa kudenja, sorcery of construction.

The second section consists of West's tracing of the path of these concepts and the people who embody and enact them across time. These include the period of Portuguese military conquest; the transition from military to administrative control; the period of Catholic proselytisation and "conversion"; the formation of Frelimo and fighting the war of independence; independence; villagisation; and structural adjustment. The third section follows this path into the period of West's own fieldwork, tracing the ways that "liberalizing patronage and patronizing liberalism" granted a new margin of manoeuvre to healers and to colonial-era officials so as better to co-opt them.

For me, this book raised a number of questions that seem central to the future of ethnographic writing in the $21^{\text {st }}$ century. First, as we think about the legacies of the kinds of encompassing philosophical viewpoints that we might call "systems of thought", how can we evaluate the interplay of pre-colonial, colonial and postcolonial ideologies and idioms? If a notion like uwavi has bridged all three eras, maintaining its salience on the Mueda Plateau, can we identify trends in its importance? Raymond Williams proposed the notion of emergent, dominant and residual tendencies among ideologies, and one has a sense that perhaps the situation West describes could suggest the neat Bell curve shape of an idea's waxing and waning in the popular imagination. In other ways, however, the image that suggests itself in Kupilikula is of a reverse Bell curve. Notions of witchcraft that were dominant in the pre-colonial and early colonial period became less important during the period of anti-colonial effervescence and into the early independence period. Liberal reforms and the uncertainties they (re)introduced into people's lives seem to have ushered uwavi back in as an emergent, and perhaps even a dominant idiom of social, economic and political life.

A related question is how different "systems of thought" interact, coexist and amplify one another. What have been the interactions and cross-fertilizations among missionary Christianity, Frelimo's liberationist Marxism, market capitalism, and Pan-Africanism? Each of them suggests an eschatology that in some ways complements and in other ways competes with the others. How does each interact with uwavi, and which ones make common cause more easily than others? West's book suggests that Marxism and uwavi can coexist rather comfortably, despite Marxism's tendency toward demystification of all beliefs in invisible worlds.

In sum, Kupilikula is beautifully written, powerfully argued and elegantly organised. Individuals come alive in the descriptions and the subtleties of social practice and ideology emerge through an ethnographic form of argumentation that has become increasingly rare, where, as Evans-Pritchard wrote in Witchcraft, Oracles and Magic, the "interpretations are contained in the facts themselves, for I have described the facts in such a way that the interpretations emerge as part of the description".

\section{Mike McGovern}

Department of Anthropology,

Yale University, USA 